\title{
Determinants of Attitude Towards Zakat on Employment Income in Nigeria
}

\author{
Abubakar U. Farouk* \\ Kano State Polytechnic, Kano, Nigeria \\ Kamil Md Idris \\ (TISSA), Universiti Utara Malaysia, Malaysia \\ Ram Al Jaffri Saad \\ (TISSA), Universiti Utara Malaysia, Malaysia \\ *Corresponding author: aufadaneji@yahoo.com
}

\section{A R T I C L E I N F O}

Article history:

Received 6 November 2017

Revised form 12 February 2018

Accepted 15 March 2018

Keywords:

Attitude, Capability, Government support, Religiosity, Zakat.

JEL Code: H 27, I 38, M 41, O 55, $\mathrm{Z} 12$

\section{A B S T R A C T}

The objective of this paper was to empirically examine the influence of perceived capability, perceived government support and religiosity as determinants of attitude towards Zakat in Nigeria. A survey questionnaire was administered on government employees and 343 valid observations were retrieved and analyzed from the survey. The PLS analysis technique was used to assess the measurement model, the structural model as well as the predictive relevance of the model of the study. The outcome of the examination disclosed the appropriateness of the model of the study as well as the analytical tool utilized. The postulated relationships were all supported. Thus, the findings, if utilized in developing policies for strengthening the attitude of employees towards Zakat, will boost Zakat collections, since a positive attitude leads to improved collections. The study establishes the efficacy and the suitability of its model on factors influencing the attitude of employees towards Zakat in Nigeria. 


\section{Introduction}

The fundamental issue on Zakat that has been the concern of the Muslim ummah for several decades is what causes the wide gap between the ideal and the actual Zakat collections (Beik \& Arsyianti, 2013; Farouk, Idris, \& Saad, 2017; Ummulkhayr, Owoyemi, Binti, \& Cusairi, 2017). Despite all its prospects, Zakat has not been functional and was relegated to the background (Bugaje, 2010). Previous studies have confirmed that almost everywhere in the Muslim world Zakat has a good prospect of solving many of society's perennial problems (Heikal, Khaddafi, \& Lhokseumawe, 2014). But this potentiality is yet to be fully realized as collections from all forms of Zakat are still very low (Farouk, Idris, \& Saad, 2017; Sapingi, Ahmad, \& Mohamad, 2011). This has caused the growing focus of research on compliance behavior, as many scholars have hypothesized that like tax, if compliance is improved, the performance of Zakat as an institution will fantastically improve (Saad \& Haniffa, 2014). Similarly, it is also argued that a positive attitude is a key that will lead to improved collections (Idris \& Ayob, 2001). Therefore, if attitude towards an object is favorable, then the success of that object is assured.

Although, Islam acknowledges the fact that differences in wealth among individual members of the society is inevitable, abject poverty and severe differences are unacceptable (Dogarawa, 2009). Wealth is not something which is just merely meant to circulate among the rich, but a lease by Allah SWT to His servants. Therefore, Zakat is aimed at allowing the flow of spiritual and material values reciprocally between the giver and the receiver (Qardawi, 2009). Nevertheless, the World Bank report showed that poverty level has been on the increase over the recent years, more especially in developing countries (Alkire, Jindra, Robles Aguilar, \& Vaz, 2017). According to Matthews (2013) many Muslim nations are characterized by many indicators of abject poverty including high population pressure, high rate of unemployment, scarcity of skills, low agricultural productivity, low per capita income and inequality, causing a huge gap between the rich and the poor. This results in many economic and social ills in those societies. Consequently, the search and exploration of effective economic strategies to fight poverty and achieve economic prosperity have been the concern of all stakeholders. In the past, different strategies have been tried at different levels by different countries to alleviate poverty. However, the strategies have failed and poverty still persists unabatedly.

Many Islamic scholars argued that Zakat is the best strategy provided by Islam aimed at reducing the wide socio-economic differences between the rich and the poor through the fair redistribution of wealth (Tlemsani \& Matthews, 2013). Thus, a major economic contribution of Zakat to the society is the fact that it has the capacity to dilute inequality and fight poverty. It was purposely established with the aim of preventing the economic exploitation of the society by fighting poverty and achieving social harmony through the compulsory 
transfer of wealth from those with surplus to those in deficit in the society. Hence, Muslim countries could utilize this divinely given tool, proved beyond doubt as a very strong technique, in fighting poverty and other societal ills (Qardawi, 2009). However, according to Shirazi and Amin (2009) many scholars are of the view that Zakat has never been fully practised in its true spirit in modern days. It is therefore, envisaged that if Zakat is revived and fully utilized as it should be, then the issue of abject poverty can be tackled effectively and totally eliminated. Thus, the case for the consideration of institutionalized almsgiving (Zakat) as a form of socio-economic tool for reducing poverty is inescapable as it is tied with wealth and income redistribution (Qardawi, 2009).

However, with all the importance Islam has attached to Zakat as its third pillar, and with all the glowing benefits that are derivable from discharging it, the question has been why do Muslims resist payment of Zakat? For instance, based on research conducted by the National Zakat Agency (BAZNAS) in Indonesia there is a huge gap between the expected and the actual collection of Zakat with a ratio of $99 \%$ to $1 \%$ respectively (Beik \& Arsyianti, 2013). The case in Nigeria is similar, as in just one of its thirty six states (Kano state), there are over 10 million people (99\% Muslims) and the state is one of the formally declared Shari'a compliant states that has a government-established agency for Zakat collection, and most of its public servants are Muslims, but Zakat performance has continually been very low compared to its potentiality. According to a report by the Nigerian national newspaper "The Guardian" of June 20, 2015, the Kano State Ministry of Finance gave the figure of 143,000 as the total number of its employees and 88.8 billion naira as their annual salary. Out of this figure 49,192 are eligible to pay Zakat (Kano State Zakat Commission, 2015). On that premise, it is estimated that after taking into account Zakat allowable expenditure, a colossal sum of about one billion Naira is expected to be generated annually as Zakat from the government employees alone in the state (Farouk, Idris, \& Saad, 2017). This scenario raises the question: what really causes the poor performance of Zakat collection?

Several studies have empirically confirmed the influence of attitude towards actual behavior (Mishra, Akman, \& Mishra, 2014; Othman \& Fisol, 2017; Thoradeniya, Prabanga \& Rebecca, 2015). However, much is not known about the determinants of attitude itself, as this aspect has been neglected by previous studies on Zakat. Thus, the novelty feature for this study is the fact that it is the first attempt to focus not on the determinants of compliance behavior, but on the determinants of attitude towards Zakat. Therefore, this study's model is unique as it focuses on examining the conceptualized key determinants of attitude as identified and subsequently discussed in the study empirically. Hence the novelty of this work stems from the fact that past studies focused on the study of attitude as a factor that influences compliance, not what influences the attitude itself. This is important because a positive improvement in the attitude of muzakkis will lead to a huge boost in Zakat collection that can generate 
a huge amount of capital that could halt dealing with riba and eradication of poverty(Mohsin, 2015). Consequently, the objective of conducting this empirical examination was to identify and conduct an empirical examination of the key determinants of attitude towards Zakat with a view to developing policies for strengthening the attitude of eligible Zakat payers towards Zakat, which will cause a boost in Zakat collections, since positive attitude leads to improved collections.

In the end, the set out objectives of the study were achieved as the study established the efficacy of its model and hence recommended its adoption in similar empirical investigations on the attitude of Zakat payers. The suitability of using PLS as a tool for analysis in scholarly writings resembling the current study has also been confirmed. Similarly, apart from complementing the extant literature in the area, this paper draws the attention of stakeholders to the invaluable significance of Zakat in cracking the hard nut of abject poverty, reducing inequality and achieving prosperity. Accordingly, the study is organized in five parts. The first part which is this section is the introduction; next is the literature review, then the research methodology, then the presentation and discussion of results and finally the concluding part.

\section{Literature Review}

Attitude is described as the degree of being favorable or unfavorable towards an object. It is the liking or disliking of an object (Oskamp Stuart, 1991). A phenomenon continuously studied by social psychologists, attitude is a great contour of human history. Oskamp Stuart (1991) argued that attitude can be studied from five view points; description, measurement, polls, theories and experiments. It has been categorized as one of the three internal factors relating to an individual's Zakat compliance behavior; the two others being religiosity and knowledge (Saad \& Haniffa, 2014). The external factors are the Zakat law, its enforcement and its administration. Similarly, in another study conducted by (Idris, Bidin, \& Saad, 2012) it was established that there is a strong relationship between attitude, religious values and behavior. It is said to be a complex construct that can be studied in both unidimension and multidimensions. This has been confirmed by many empirical examinations in different fields (Saad \& Haniffa, 2014).

Studies on the attitude of eligible Zakat payers in the past were majorly on its capacity as an independent variable. Evidence from the literature on the determinants of attitude itself are limited (Azman \& Bidin, 2015). The reason for this as opined by Farouk et al. (2017) and Mohsin (2015) was the serious neglect of the subject and the - nonchallant attitude of the stakeholders in exploring its vast promising potentiality.However, many studies have theoretically and empirically confirmed that attitude is a very strong determinant of behavioral 
compliance. For instance, Saad and Haniffa (2014) revealed that attitude is positively related to Zakat on business compliance behavior. Moreover, the discourse by on identifying the most important variables correlated with the attitude construct has been ongoing (Anderson, Kreiser, \& Hornsby, 2011). Nevertheless, recently scholarly discussions on Zakat is attracting a lot of attention with a high concentration of literature in Muslim countries such as Saudi Arabia, Pakistan, Malaysia, Indonesia and Jordan. Similarly, serious research efforts are being made in developed non-Islamic countries such as UK and USA (Ummulkhayr et al., 2017).

Thus, in that line, Saad and Haniffa (2014) suggested the need for more empirical investigations on the determinants of attitude toward Zakat compliance behavior as its importance in behavioral studies cannot be discounted. Moreover, Billah (2016) established that Zakat is an effective result-oriented alternative to achieve the much needed modern social security system.Accordingly, this study is set to empirically examine the influence of religiosity, capability and government support on attitude towards Zakat.

Perceived capability is one of the three independent variables in the model of the study considered as a key determinant of attitude towards Zakat. Pavlou and Fygenson (2006) reported that Bandura (1986) defined self-efficacy to mean an individual's perception of a person's capabilities to perform a behavior. It affects and is evident on an individual's feelings, thinking, and action. Capability is operationalized in this study to mean self-efficacy. It is the degree of an individual's confidence on the ability to perform an action (Ling, 2012). It is the easiness or the difficulty in the performance of a behavior, in other words, the perceived individual's ability to perform a behavior (Wang \& Clung, 2011). For instance, a person could be motivated to give as a result of observing others also giving and having confidence in their capacity to give, particularly if it is perceived that what is given may positively impact the targeted beneficiary. Perhaps considering volitional control over behavior as a matter of degree rather than kind, has confirmed that even ordinary daily behaviors (attitudes) may have not only the positive impact but may as well have unpredicted impediments (Mullan, Wong, \& Kothe, 2013). Hence it could be presumed that greater confidence influences attitude towards compliance.

Results from past studies were mixed on the relationship between capability and intention (Ifinedo, 2012; Shin, 2009; Yang, 2012), while research on capability as a determinant of attitude are few in the literature which scholars have cautioned on generalizing such findings (Khamis \& Yahya, 2015; Khamis et al., 2014; Oladimeji et al., 2013; Rahman \& Omar, 2010). It is thus not known whether capability will have an influencing effect on the attitude of employees towards compliance; more so that capability is not a generalized phenomenon that reflects a universal personality trait, but rather varies among different behavioral spheres (Ifinedo, 2012). 
Theoretically it is postulated that capability influences attitude towards compliance. A study in this regard is important to test the applicability of the postulated hypothesis and to establish whether the assumptions may work on civil servants in complying with the payment of Zakat and whether new facts may emerge for the government to formulate policies that focused on attitudes to encourage Zakat voluntary compliance by government workers. As such this study tested the hypothesis that:

$\mathrm{H}_{1}$ : Perceived capability is significantly related to attitude towards Zakat.

Perceived government support was also identified as a key determinant of attitude towards Zakat. It was considered as a controllability factor as described by (Ajzen, 2002). Controll is personal judgments on the availability of resources and the opportunities to perform a certain behavior. According to Ajzen (2002) to controllability means "individual judgments about the availability of resources and opportunities to perform a behavior". According to Ajzen and Sheikh (2013) it is a reflection of a person's perception on the needed resources, opportunities and skills in performing a behavior. In this study, government support describes how an employee perceives government support in providing facilities that will assist in the process of Zakat. In a nutshell government support refers to facilitating conditions.

It has been established by many past studies that government support influences attitude towards compliance (Al-Majali \& Nik Mat, 2010; Mahmoud, 2011; Tan \& Teo, 2000). For instance, Tan and Teo (2000) found that government support provides feasibility and credibility to attitude/behavior, making it more acceptable to individuals. Thus, government support was adjudged as a key motivating force that can encourage persons to perceive more favorably an object of attitude. Thus, in testing the influence of government support on attitude towards Zakat, new facts may emerge as to how to strengthen attitude towards Zakat as it will guide government and other Zakat stakeholders in finding specific required actions to encourage voluntary compliance by not only civil servants but employees of the private sector as well.

$\mathrm{H}_{2}$ : Perceived government support is significantly related to attitude towards Zakat.

Another identified fundamental determinant of attitude towards Zakat is religiosity. Zakat is financial worship and as such religiosity cannot be discounted as part of the determinants of attitude towards Zakat. Religion is considered as one of the universally most recognized important social institutions that build and shape human behavior at both personal and societal levels. Thus, religious beliefs affect human behavior symbolically and ritualistically (Khraim, 2010). Pope and Mohdali (2011) defined religiosity as "the extent to which an 
individual is committed to the religion he or she professes and its teachings, such that individual attitudes and behaviors reflect this commitment". Contrary to tax researches, modern studies on Zakat focus more on sociological and psychological rather than economic deterrence factors. However, investigations on the impact of religiosity on attitude towards compliance is now relatively gaining prominence in the literature (Idris \& Ayob, 2001). Nevertheless, it is obvious that more theoretical and empirical research is needed to bridge the several gaps in the area.

Islamic religiosity is believing in Allah SWT who is entitled to be worshipped and obeyed and one should conduct one's life in accordance to the principles, values and rules of Islam. It has been established that religiosity affects societal and individual behavior (Pope \& Mohdali, 2011). On this note, it is assumed that a person's religious belief is always used in his/her everyday activities although to varying extents.

Many researchers have empirically attempted to measure Islamic religiosity such as Khraim (2010), Muhamad and Mizerski (2013) on marketing, Idris et al. (2012) on Zakat on business income compliance, Idris and Ayob (2001) on attitudes towards Zakat, and Abu Bakar et al. (2010) on motivations of paying on income. All have agreed that measurements of Islamic religiosity must cover three aspects which are the current Islamic issues, religious education and sensitive products. From the foregoing it could be deduced that a person with high religiosity will be more inclined to have a more favorable disposition on compliance behavior than a person considered to be of not high religiosity. It is therefore postulated that:

$\mathrm{H}_{3}$ : Religiosity is significantly related to attitude towards Zakat.

\section{Methodology}

This section presents details on the conceptual model of the study, the operationalization as well as the measurement items of each of the constructs. Additionally, the population, the sampling and the data analysis technique utilized for the study are all detailed. There are three independent variables (perceived capability, perceived government support and religiosity) and one dependent variable (attitude towards Zakat).

The model as depicted in Figure 1 was developed based on the literature reviewed. The model shows the direct relationship between the three independent variables (perceived capability, perceived government support and religiosity) and the dependent variable of the study (attitude towards Zakat). Accordingly, as discussed earlier, three hypotheses were developed to test whether there is a significant relationship between each of the exogenous constructs and the endogenous construct (attitude) as conceptualized. 


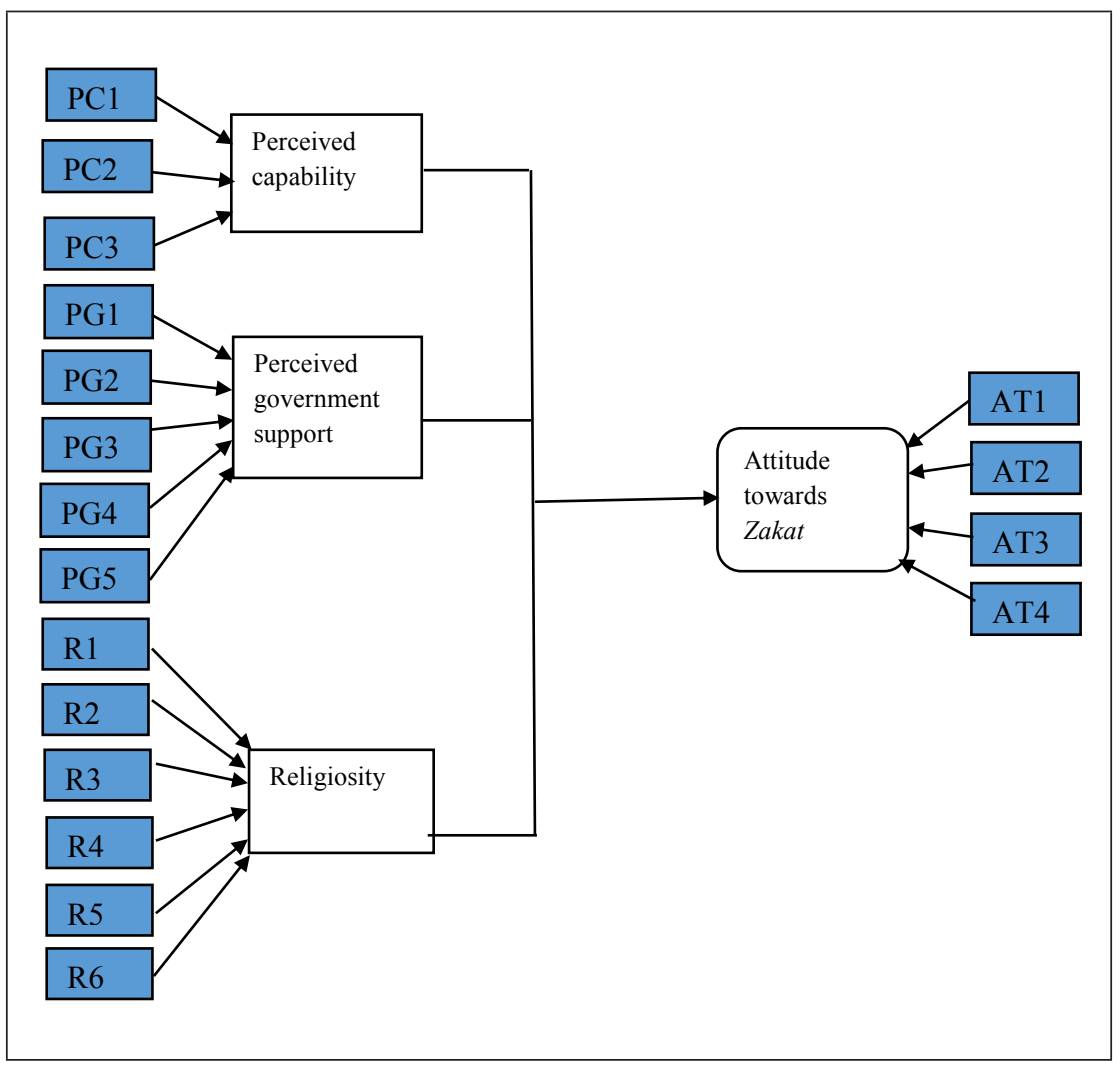

Figure 1. Conceptual Model of the Study.

The items of measurements in the questionnaire were adapted from past studies in line with the operationalization of the constructs. All the items were measured using the 5-point Likert scale, from 1 representing strongly disagree to 5 representing strongly agree (Sekaran, 2003). Nevertheless, consequent upon the validity and reliability tests including the common bias test, a total of four items were deleted as they failed to achieve the set criteria as per the recoomendations of Hair, Hollingsworth, Randolph and Chong (2017) which prescribe the acceptability threshold as VIF and tolerance of less than 5 and tolerance above .2 as well as AVE of at least .5 and a composite reliability of at least.708 as discussed in detail subsequently under the measurement model assessment. As presented in Table 1, the items deleted were. AT2 in attitude and R2, R3, R4 in religiosity. Thus, 11 items were retained as follows; three items to measure attitude, three items for perceived capability, five items for perceived government support and three items for religiosity. 
Table 1. Summary of Measurements

\begin{tabular}{|c|c|c|}
\hline Item & Question & Sources \\
\hline AT1 & It is good for me to pay Zakat. & Adapted from Idris \& Ayob (2001). \\
\hline AT2 & It is my priority to pay Zakat. & Adapted from Idris \& Ayob (2001). \\
\hline AT3 & I like to pay Zakat. & Adapted from Idris \& Ayob (2001). \\
\hline AT4 & $\begin{array}{l}\text { I am happy to pay Zakat when so many } \\
\text { others are not paying. }\end{array}$ & Adapted from Idris \& Ayob (2001). \\
\hline PC1 & It will be possible for me to pay Zakat. & $\begin{array}{l}\text { Adapted from Alam, Janor, } \\
\text { Zanariah, Wel, and Ahsan (2012) } \\
\text { and Ajzen (2006). }\end{array}$ \\
\hline PC2 & If I wanted to I could pay my Zakat. & $\begin{array}{l}\text { Adapted from Alam, Janor, } \\
\text { Zanariah, Wel, and Ahsan (2012) } \\
\text { and Ajzen (2006). }\end{array}$ \\
\hline PC3 & I am confident that I can pay my Zakat. & $\begin{array}{l}\text { Adapted from Alam, Janor, } \\
\text { Zanariah, Wel, and Ahsan (2012) } \\
\text { and Ajzen (2006). }\end{array}$ \\
\hline PG1 & $\begin{array}{l}\text { The government endorses the payment of } \\
\text { Zakat. }\end{array}$ & $\begin{array}{l}\text { Adapted from Muhamad et al. } \\
(2006) \text {. }\end{array}$ \\
\hline PG2 & $\begin{array}{l}\text { The government is active in setting up the } \\
\text { facilities to enable the payment of Zakat. }\end{array}$ & $\begin{array}{l}\text { Adapted from Muhamad et al. } \\
(2006) \text {. }\end{array}$ \\
\hline PG3 & $\begin{array}{l}\text { The government promotes the payment of } \\
\text { Zakat. }\end{array}$ & $\begin{array}{l}\text { Adapted from Muhamad et al. } \\
(2006) \text {. }\end{array}$ \\
\hline PG4 & $\begin{array}{l}\text { The government encourages the payment } \\
\text { of Zakat. }\end{array}$ & $\begin{array}{l}\text { Adapted from Muhamad et al. } \\
(2006) \text {. }\end{array}$ \\
\hline PG5 & $\begin{array}{l}\text { The current Zakat payment system } \\
\text { provided by the government is } \\
\text { convenient. }\end{array}$ & $\begin{array}{l}\text { Adapted from Muhamad et al. } \\
(2006) \text {. }\end{array}$ \\
\hline $\mathrm{R} 1$ & I regularly offer prayers five times a day. & Adapted from Idris et al. (2012). \\
\hline $\mathrm{R} 2$ & $\begin{array}{l}\text { Allah will punish believers who do not } \\
\text { pay Zakat. }\end{array}$ & Adapted from Idris et al. (2012). \\
\hline R3 & I regularly recite the holy Qur'an. & Adapted from Idris et al. (2012). \\
\hline $\mathrm{R} 4$ & I fast regularly. & Adapted from Idris et al. (2012). \\
\hline R5 & $\begin{array}{l}\text { I feel guilty to commit minor and major } \\
\text { sins. }\end{array}$ & Adapted from Idris et al. (2012). \\
\hline R6 & $\begin{array}{l}\text { I try to follow Islamic injunctions in all } \\
\text { matters of my life. }\end{array}$ & Adapted from Idris et al. (2012). \\
\hline
\end{tabular}


The population of the study consisted of 49,912 employees working in various government offices in Kano state, Nigeria. Krecie and Morgan's rule of thumb was used to arrive at the sample size of 381 which also met Hair, Sarstedt, Ringle, and Mena's (2012) requirement of a minimum ratio acceptable based on the variables of the study. A total of 495 copies of the questionnaire were distributed to the government workers that were chosen as the unit of analysis. However, out of the distributed questionnaires, 356 representing $72 \%$ were retrieved. A total of 13 responses were removed as a result of double clicking and poor completion of the questionnaire by the respondents. Consequently, only 343 responses representing $69 \%$ were actually used for the analysis. This was considered adequate and acceptable for environments like Nigeria, where the response rate to research instruments is very low (Alabede, 2014).

The Partial Least Square (PLS-SEM) path modeling was employed to examine the influence of the predictor variables: perceived capability, perceived government support and religiosity on the criterion variable of the study; and attitude towards Zakat. Hair, et al. (2014) suggested it as a suitable data analysis tool in studies such as this where new frontiers are being reconnoitred.

\section{Presentation and Discussion of Results}

The data underwent preliminary screening including the test for multicollinearity and was then followed by the main data analysis. This involved the assessment of the measurement model, the evaluation of the structural model and the appraisal of the blind-folding procedure. The results revealed the non-existence of multicollinearity. The VIF values were all not more than the maximum standard score of 5 as recommended by Hair et al. (2017); and Sekaran and Bougie (2016). The scores were 1.236, 1.385 and 1.508 for perceived capability, perceived government support and religiosity respectively.

\subsection{Measurement Model}

Table 1 and Figure 2 provide details of the assessment of the measurement model analysis involving convergent validity and discriminant validity (Hair et al., 2017; Hair, Hult, Ringle, \& Sarstedt, 2014). As reflected in Table 2 the loadings of all the items were between .629 (AT1) and .933 (PC2) and the composite reliability scores were good (above the acceptable .70), ranging between .781 (religiosity) and .929 (capability) (Hair et al., 2017). Moreover, the AVE of all the constructs were higher than the minimum standard of .5 (Hair et al., 2017). Thus, convergent validity was confirmed for all the models' constructs and items of measurement. 
Table 2. The Measurement Model Summary (Result for Reflective)

\begin{tabular}{llccc}
\hline \multicolumn{1}{c}{ Latent Variable } & Indicator & Loadings & $\begin{array}{c}\text { Composite } \\
\text { reliability }\end{array}$ & AVE \\
& AT1 & 0.629 & 0.811 & 0.592 \\
Attitude & AT3 & 0.837 & & \\
& AT4 & 0.824 & & \\
Capability & PC1 & 0.893 & 0.929 & 0.813 \\
& PC2 & 0.933 & & \\
Government support & PC3 & 0.878 & & \\
& PG1 & 0.862 & 0.925 & \\
& PG2 & 0.902 & & \\
& PG3 & 0.860 & & \\
& PG4 & 0.787 & & \\
Religiosity & PG5 & 0.805 & & \\
& R1 & 0.685 & 0.781 & \\
& R5 & 0.749 & & \\
& R6 & 0.774 & & \\
\hline
\end{tabular}

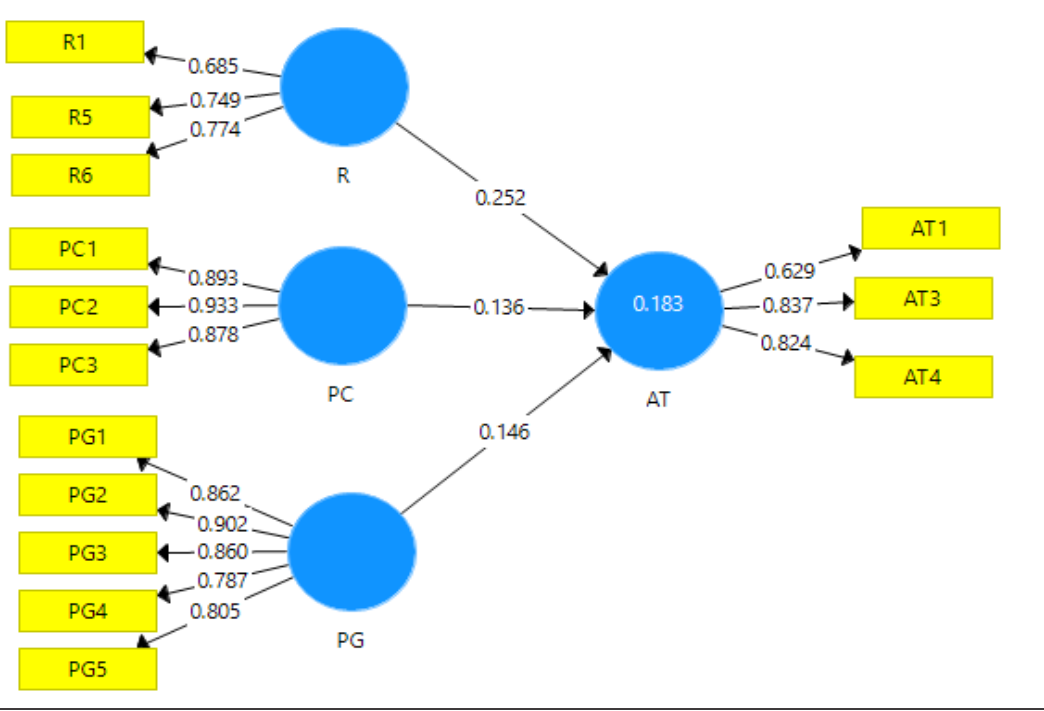

Figure 2. Measurement Model

To establish discriminant validity the HTMT method was used as recommended by (Hair et al., 2017; Hair et al., 2014). The HTMT ratio assessment results indicated that the correlations of the indicators across the constructs were measuring different phenomena relative to the correlations of the indicators within the same construct in the model in accordance with the standard benchmark. 
Accordingly, the detailed statistical results as shown in Table 3 indicate that the scores for each construct compared to the threshold of the Heterotrait-Monotrait Ratio (HTMT). According to Henseler, Ringle and Sarstedt (2014) the value of the HTMT should be lower than 0.85 as per (Kline, 2011) or 0.90 as per (Gold et. al, 2011). Accordingly, all the constructs of the model of the study have achieved discriminant validity as none is higher than .85 .

Table 3. Heterotrait-Monotrait Ratio (HTMT)

\begin{tabular}{lcccc}
\hline & AT & PC & PG & R \\
\hline AT & & & & \\
PC & 0.383 & & & \\
PG & 0.411 & 0.361 & & \\
R & 0.630 & 0.586 & 0.707 & \\
\hline
\end{tabular}

\subsection{Structural Model Assessment}

The structural model assessment was conducted through the examination of the significance of the path coefficients, the level of $\mathrm{R}^{2}$ (coefficient of determination), the effect size $\left(\mathrm{f}^{2}\right)$ and the predictive relevance (Hair et al., 2011).

The outcome of the bootstrapping procedure showed the structural relationships are significant. Table 4 and Figure 3 revealed that the relationship between perceived capability and attitude towards Zakat results in $(\beta=0.138$, $\mathrm{p}<0.015)$. Similarly, the relationship between perceived government support and attitude towards Zakat indicates a $(\beta=0.143, \mathrm{p}<0.010)$. In the same way, the relationship between religiosity and attitude towards Zakat shows $(\beta=0.260$, $\mathrm{p}<0.000)$. By implication all the three hypothesized relationships of the model of the study proved to be positively significant. It is therefore, concluded that perceived capability, perceived government support and religiosity have direct significant and positive relationships in influencing attitude towards Zakat. However, religiosity is the strongest, followed by perceived government support and then lastly perceived capability.

Table 4. Results of Hypotheses Testing

\begin{tabular}{lcccc}
\hline & Beta & Standard error & t-value & Decision \\
\hline PC ->AT & 0.138 & 0.056 & $2.431^{*}$ & Supported \\
PG ->AT & 0.143 & 0.057 & $2.580^{*}$ & Supported \\
R ->AT & 0.260 & 0.053 & $4.720^{* *}$ & Supported \\
\hline
\end{tabular}

Note. ${ }^{*} * \mathrm{p}<0.01,{ }^{*} \mathrm{p}<0.05$ (based on one-tailed test) 


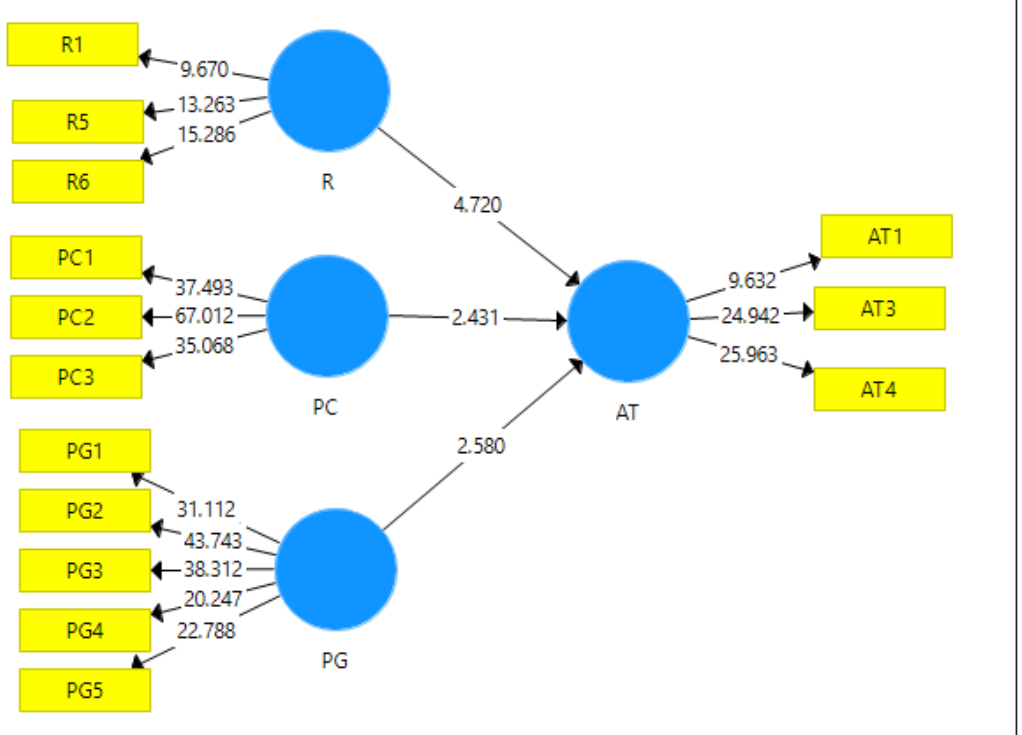

Figure 3. Structural Model

Similarly, $\mathrm{R}^{2}$ which explains the percentage variation of the model is $17.5 \%$ (Hair et al., 2011). This is an indication that there are other factors not covered by this study that could contribute $82.5 \%$ influence and explanation of the attitude towards Zakat, which further research should attempt to explore.

Additionally, the $\mathrm{f}^{2}$ results of this study as shown in Table 5 reveals that all the exogenous constructs are having small effect sizes, although religiosity is a bit higher than perceived capability and perceived government support. This is in line with the criteria of evaluating the effect size by Cohen (1992), that scores of $0.02,0.15$, and 0.35 , represent a small, a medium, and a large effect size.

Table 5. Determination of Effect Size $\left(\mathrm{f}^{2}\right)$ and Rating in the Structural Model

\begin{tabular}{lcc}
\hline Independent Variables & Effect Size $\left(f^{2}\right)$ & Rating \\
\hline PC $->$ AT & 0.02 & Small \\
PG $->$ AT & 0.02 & Small \\
R $->$ AT & 0.05 & Small \\
\hline
\end{tabular}

The predictive accuracy and quality model of the study was appraised by assessing the predictive relevance $\left(\mathrm{Q}^{2}\right.$ value $)$ otherwise known as the blindfolding procedure in accordance with (Geisser, 1974; Stone, 1974). Results of the blindfolding procedure indicated a $\mathrm{Q}^{2}$ value of 0.095 , which is greater than zero. Consequently, the predictive quality of the model is confirmed. 
Thus, from the literature it has been established that the fundamental challenge facing Muslim societies on the functionality of Zakat system today is how to boost its collections. Low collections lead to the weakness of the functionality of the Zakat system to achieve its main purpose of diluting inequality and effective poverty reduction. Boosting collections means more revenue to distribute to the Mustahikkin and this can be guaranteed by paying more attention and strategizing on the attitude of the Zakat payers as confirmed by the results in this study. Evidence has been provided on the impact of attitude of eligible Zakat payers' attitude toward Zakat, because all the three hypotheses tested were found to be significant; perceived capability, perceived government support and religiosity were all significantly related to attitude towards Zakat.

For instance, the variable perceived capability is significantly related to attitude towards Zakat. This is a clear indication that the eligible Zakat payers' degree of confidence in their disposition towards Zakat is favorable. They perceive easiness towards the performance of the Zakat. As such, improved perceived capability means improved attitude towards Zakat. Although studies on capability as a determinant of attitude are few in the literature, the finding in this study is consistent with previous studies like Ling (2012). Granted that the studies differ in areas of study with this study, the findings in this study provide support that perceived capability plays an important role in improving the attitude of eligible Zakat payers. This implies that stakeholders, particularly the government organs saddled with the responsibility of Zakat collection, should put in more effort in creating the necessary awareness on the easiness of Zakat payment so that more collections could be realized.

Similarly, perceived government support has also been confirmed to be significantly related to attitude towards Zakat. It has been operationalized as the facilitating condition in the form of providing facilities that will assist in the payment of Zakat. It was adjudged from the results as a key motivating force that encourages a person to perceive more favorably on attitude towards Zakat. The result is in line with the findings of similar studies such as Al-Majali and Nik Mat (2010), Farouk, Idris, and Saad (2017), Mahmoud (2011), and Tan and Teo (2000) which all confirm the influence of government support on attitude. Thus, the government through the Zakat institutions should make an effort in the provision of facilities that will ease the payment of Zakat by eligible payers. These facilities include deducting Zakat on employment income at the source, providing incentives for the payment of Zakat through granting tax rebate, considering Zakat due as a tax deductible expense, etc. They should also endeavor to provide detailed information instantly at the request of Zakat payers to help in the calculation and payment of Zakat. If these strategies are put to use more Zakat collections can be expected from those already paying and more from others that the suggested strategies create. 
Moreover, this study infers that religiosity is a major influencer of attitude towards Zakat. The results have confirmed this inference and supported the hypothesis developed in that respect. Thus, a highly religious person will have a positive attitude towards paying Zakat as compared to a person who is not highly inclined to religiosity. This position is aligned with the findings of past studies on subjects such as Azman \& Bidin (2015), R. M. Khamis et al.(2014) and Pope, 2014) on Zakat on savings, Zakat of SMEs and taxation respectively. Therefore, Zakat establishments can do more in terms of Zakat collection by developing distinct policies that will further encourage those highly religious and attract those not highly religious through organizing educative programs in masjids and other religious avenues and places of worship, while government should focus on awareness creation through other forms of reaching out to those not highly religious, such as the distribution of pamphlets and other forms of promotions through the social media, radio, newspapers, television and so on. This idea if implemented will enhance knowledge and awareness on the importance of paying Zakat by eligible payers and this will consequently improve Zakat collections that will be available for distribution to eligible recipients and hence dilute the wide gap in economy within the society.

\section{Conclusion}

This paper empirically examined the influence of perceived capability, perceived government support and religiosity as determinants of attitude towards Zakat. The objective of this empirical examination was to find out the keys expected to enhance the attitude of Zakat payers and boost Zakat collections to fight poverty. Moreover, it was also aimed at establishing the appropriateness of the model of the study as well as the suitability of PLS-SEM in examining the determinants of attitude towards Zakat. To this end, relevant literature was reviewed on the three determinants in the model and the need for all stakeholders to focus more attention on the examined key determinants of attitude towards Zakat was emphasized for Zakat collection to be improved significantly.

A survey questionnaire was administered on government employees and 343 valid observations representing $69 \%$ of the population were retrieved and analyzed. The PLS analysis technique was used in assessing the measurement model, the structural model as well as the predictive relevance of the model of the study. Hair, et al. (2014) suggested it as a suitable data analysis tool for studies such as this as new frontiers are being reconnoitered.

The postulated relationships were all supported. Accordingly, the outcome of the examination disclosed the importance of the identified determinants of attitude towards Zakat and the suitability of the model of the study as well as the appropriateness of the analytical tool utilized. Thus, the findings, if utilized 
in developing policies for strengthening the attitude of eligible Zakat payers, will boost Zakat collections, since a positive attitude will lead to improved collections.

The study complements the limited extant literature in the area which is considered a major contribution especially as it affects Zakat on employment income which suffers neglect among all other types of Zakat particularly in environments such as Kano Nigeria. Moreover, the findings of this study could be utilized for developing policies for strengthening the attitude of eligible Zakat payers towards Zakat, which will lead to an increase in Zakat collections. Besides, the study is also unique as it establishes the efficacy of its model and hence recommends its adoption in similar empirical investigations on the attitude of Zakat payers in future. The suitability of using PLS as a tool for analysis in scholarly writings resembling the current study has also been confirmed.

In a nutshell, this paper draws the attention of stakeholders to the invaluable significance of studying the determinants of attitude towards Zakat with the aim of improving Zakat collections for cracking the hard nut of abject poverty, reducing inequality and achieving economic prosperity.

Finally, part of the limitations of this research work is that data was collected from civil servants only, despite the fact that Zakat is obligatory not only on civil servants, but also on others. Thus, it is suggested that future research should pay attention to other eligible Zakat payers engaged in Zakatable undertakings not covered in this study. These include business men, professionals, farmers and so on. Furthermore, a replication of the study is also recommended in other similar locations to further confirm the results obtained.

\section{References}

Abu Bakar, N. B., \& Abdul Rashid, H. M. (2010). Motivations of paying Zakat on income: Evidence from Malaysia. International Journal of Economics and Finance, 2(3), 76-85.

Ajzen, I. (2002). Perceived behaviour control, self-efficacy, locus of control and the theory of planned behaviour. Journal of Applied Social Psychology, In Press.

Ajzen, I., \& Sheikh, S. (2013). Action versus inaction: Anticipated affect in the theory of planned behavior. Journal of Applied Social Psychology, 43(1), $155-162$.

Al-Majali, M., \& Nik Mat, N. K. (2010). Application of decomposed theory of planned behavior on Internet banking adoption in Jordan. Journal of Internet Banking and Commerce, 15(2), 1-7.

Alabede, J. O. (2014). An exploratory analysis of individual taxpayers' compliance behaviour in Nigeria: A study of demographic differences and impact. International Journal of Accounting and Taxation, 2(2), 39-64. 
Alam, S. S., Janor, H., Zanariah, Wel, C. A. C., \& Ahsan, M. N. (2012). Is religiosity an important factor in influencing the intention to undertake Islamic home financing in Klang Valley? World Applied Sciences Journal, 19(7), 1030-1041.

Alkire, S., Jindra, C., Robles Aguilar, G., \& Vaz, A. (2017). Multidimensional poverty reduction among countries in sub-Saharan Africa. In Forum for Social Economics (pp. 1-14). Taylor \& Francis.

Anderson, B. S., Kreiser, P., \& Hornsby, J. S. (2011). Attitude, behavior, or both? An empirical investigation of the entrepreneurial orientation construct. In Frontiers of Entrepreneurship Research (Vol. 31, p. 619).

Azman, F. M. B. N., \& Bidin, Z. Bin. (2015). Determinants of attitude toward Zakat on saving. Australian Journal of Basic and Applied Sciences, 9(31), 7-13.

Beik, I. S., \& Arsyianti, L. D. (2013). Optimization of Zakat instrument in Indonesia's poverty alleviation programme, 1-19.

Bidin, Z. Bin, \& Idris, K. M. (2007). A confirmatory analysis of zakat compliance behavioural intention on employment income. Malaysian Management Journal, 11(1\&2), 103-114.

Billah, M. M. (2016). Creating an eco-sustainable community: The role of Zakat. International Journal of Zakat, 1(1), 1-16. Retrieved from http://www. puskasbaznas.com/ijaz/index.php/journal/article/view/5

Bugaje, U. (2010). The administration of Zakat in colonial and post colonial Nigeria.

Cohen, J. (1992). A power primer. Psychological Bulletin, 112(1), 155.

Dogarawa, A. B. (2009). Poverty alleviation through Zakat and Waqf Institutions: A case for the Muslim ummah in Ghana. In First National Muslim Summit.

Farouk, A. U., Idris, K. B., \& Saad, J. B. (2017). The challenges of Zakat management: A case of Kano State, Nigeria. Asian Journal of Multidisciplinary Studies, 5(7), 142-147.

Farouk, A. U., Idris, K. B., \& Saad, R. A. B. (2017). Predicting the intention of civil servants to pay Zakat. International Journal of Innovative Knowledge Concepts, 5(7), 21-29.

Geisser, S. (1974). A predictive approach to the random effect model. Biometrika, 61(1), 101-107.

Hair, J. F., Hult, G. T. M., Ringle, C. M., \& Sarstedt, M. (2014). A primer on partial least squares structural equation modeling (PLS-SEM). A. Hutchinsm \& V. Knight, (Eds.) (1 $1^{\text {st }}$ ed). Wasington DC: SAGE Publications, Inc.

Hair, J. F., Ringle, C. M., \& Sarstedt, M. (2011). PLS-SEM: Indeed a silver bullet. The Journal of Marketing Theory and Practice, 19(2), 139-152. 
Hair, J. F., Sarstedt, M., Ringle, C. M., \& Mena, J. A. (2012). An assessment of the use of partial least squares structural equation modeling in marketing research. Journal of the Academy of Marketing Science, 40(3), 414-433.

Hair, J., Hollingsworth, C. L., Randolph, A. B., \& Chong, A. Y. L. (2017). An updated and expanded assessment of PLS-SEM in information systems research. Industrial Management \& Data Systems, 117(3), 442-458.

Heikal, M., Khaddafi, M., \& Lhokseumawe, U. M. (2014). The intention to pay Zakat commercial: An application of revised theory of planned behavior. Journal of Economics and Behavioral Studies, 6(9), 727-734.

Henseler, J., Ringle, C. M., \& Sarstedt, M. (2014). A new criterion for assessing discriminant validity in variance-based structural equation modeling. Journal of the Academy of Marketing Science, 43(1), 115-135.

Idris, K. M., \& Ayob, A. M. (2001). Attitude towards zakat on employment income: Comparing outcomes between single score and multidimensional scores. Malaysian Management Journal, 5(1\&2), 47-63.

Idris, K. M., Bidin, Z., \& Saad, R. A. J. (2012). Islamic religiosity measurement and its relationship with business income zakat compliance behavior. Jurnal Pengurusan, 34, 3-10.

Ifinedo, P. (2012). Understanding information systems security policy compliance: An integration of the theory of planned behavior and the protection motivation theory. Computers and Security, 31(1), 83-95.

Kano State Zakat and Hubsi Commission. (2015). Record of Zakat payers. Kano.

Khamis, M. R., \& Yahya, N. C. (2015). Does law enforcement influence compliance behaviour of business Zakat among SMEs ?: An evidence via Rasch measurement model. GJAT, 5(1), 19-32.

Khamis, R. M., Mohd, R., Salleh, A., \& Nawi, A. S. (2014). Do religious practices influence compliance behaviour of business Zakat among SMEs? Journal of Emerging Economies and Islamic Research, 2(2), 1-16. Retrieved from http://www.jeeir.com/index.php/jeeir/article/ view/115/46

Khraim, H. (2010). Measuring religiosity in consumer research from an Islamic perspective. Journal of Economic and Administrative Sciences, 26(1), 52-78.

Ling, H. E. (2012). A study of the relationship between indicators and public donation intention in Penang: A perspective of planned behavior theory with inclusion of some cognitive factors.

Mahmoud, M. A. (2011). Market orientation and business performance among SMEs in Ghana. International Business Research, 4(1). Retrieved from Www.ccsenet.org/ibr

Mishra, D., Akman, I., \& Mishra, A. (2014). Theory of reasoned action application for green information technology acceptance. Computers in Human Behavior, 36, 29-40. 
Mohsin, M. I. A. (2015). Potential of Zakat in eliminating riba and eradicating poverty in Muslim countries \{Case Study: Salary deduction scheme of Malaysia . International Journal of Islamic Management and Business, 1(1), 40-63.

Muhamad, M., Ainulashikin, M., \& Amir, S. (2006). Factors influencing individual participation in zakat contribution: Exploratory investigation. Seminar for Islamic Banking and Finance 2006 (iBAF2006), 1-10.

Muhamad, N., \& Mizerski, D. (2013). The effects of following Islam in decisions about taboo products. Psychology \& Marketing, 30(6), 356-371.

Mullan, B. a., Wong, C., \& Kothe, E. J. (2013). Predicting adolescents' safe food handling using an extended theory of planned behavior. Food Control, 31(2), 454-460.

Mustafa, M. O. A., Mohamad, M. H. S., \& Adnan, M. A. (2013). Antecedents of zakat payers' trust in an emerging zakat sector: An exploratory study. Journal of Islamic Accounting and Business Research, 4(1), 4-25.

Oskamp Stuart. (1991). Attitudes and opinions. New Jersey: Liveright Publishing Corporation.

Othman, Y., \& Fisol, W. (2017). Islamic religiosity, attitude and moral obligation on intention of income Zakat compliance: Evidence from public educators in Kedah. Journal of Academic Research in Business .... Retrieved from http://hrmars.com/hrmars_papers/Islamic_Religiosity,_Attitude_and_ Moral_Obligation_on_Intention_of_Income_Zakat_Compliance.pdf

Pavlou, P. a., \& Fygenson, M. (2006). Understanding and predicting electronic commerce adoption: An extension of the theory of planned behavior. Mis Quarterly, 30(1), 115-143.

Pope, J. (2014). The influence of religiosity on taxpayers' compliance attitudes empirical evidence from mixed-methods.

Pope, J., \& Mohdali, R. (2011). The role of religiosity in tax morale and tax compliance. Australian Tax Forum, (25), 565-596.

Qardawi, Y. (2009). Fiqh Al Zakah.

Rahman, A. A., \& Omar, S. (2010). Epistemology in increasing the number of Zakat-of-wealth payers and its contribution toward the development of Malaysia. ... Conference-The Tawhidi Epistemology ..., 53-63. Retrieved from http://www.ukm.edu.my/hadhari/sites/default/files/prosiding/ p4.pdf

Saad, R. A., \& Haniffa, R. (2014). Determinants of zakat (Islamic tax) compliance behavior. Journal of Islamic Accounting and Business Research, 5(2), 182-193.

Sapingi, R., Ahmad, N., \& Mohamad, M. (2011). A study on zakat of employment income: Factors that influence academics' intention to pay zakat. 2nd International Conference on Business and Economic Research, (April), 2492-2507. 
Sekaran, U. (2003). Research methods for business. J. Marshall, (Ed.), (4 ${ }^{\text {th }}$ ed). New York: John Wiley and Sons, Inc. https://doi.org/10.1017/ CBO9781107415324.004

Sekaran, U., \& Bougie, R. (2016). Research methods for business: A skill building approach. John Wiley \& Sons.

Shin, D. H. (2009). Towards an understanding of the consumer acceptance of mobile wallet. Computers in Human Behavior, 25(6), 1343-1354.

Shirazi, N. S., \& Bin Amin, M. F. (2009). Poverty elimination through potential zakat collection in the OIC-member countries: Revisited. Pakistan Development Review, 48(4), 739-753.

Stone, M. (1974). Cross-validatory choice and assessment of statistical predictions. Journal of the Royal Statistical Society. Series B (Methodological), 111-147.

Tan, M., \& Teo, T. S. H. (2000). Factors influencing the adoption of Internet banking. Journal of the AIS, 1, 1-42.

Thoradeniya, P., \& Rebecca, L. (2015). Sustainability reporting and the theory of planned behaviour. Accounting, Auditing and Accountability Journal, 28(7), 1099-1137.

Tlemsani, I., \& Matthews, R. (2013). Zakat and the elimination of poverty: New perspectives. International Journal of Information Technology and Business Management, 9(1), 54-69.

Ummulkhayr, A., Owoyemi, M. Y., Binti, R., \& Cusairi, M. (2017). Determinants of Zakat compliance behavior among Muslims living under non-islamic governments. International Journal of Zakat, 2(1), 95-108.

Xiao Wang, \& McClung, S. R. (2011). Toward a detailed understanding of illegal digital downloading intentions: An extended theory of planned behavior approach. New Media \& Society, 13(4), 663-677.

Yang, K. (2012). Consumer technology traits in determining mobile shopping adoption: An application of the extended theory of planned behavior. Journal of Retailing and Consumer Services, 19(5), 484-491. 